\title{
The education policies of international organizations: Specific differences and convergences
}

\author{
Abdeljalil Akkari · Thibaut Lauwerier
}

Published online: 11 December 2014

(C) UNESCO IBE 2014

\begin{abstract}
This article analyzes the role that international organizations play in orienting education reforms and changes, based on an examination of key texts these organizations produced in the 1990s. The analysis shows that some specific trends persist: UNESCO and UNICEF centre their philosophy on a humanistic and child-centered vision of education, while the World Bank and the OECD give priority to education policy based on assessing skills and learning outcomes. Over the past decade, however, among the major international organizations involved in education, there has been a gradual convergence in the vision of education, towards learning outcomes. This convergence is illustrated by looking at several topics of common concern: quality, good governance, accountability, privatization, benchmarking, and the measurement of learning outcomes.
\end{abstract}

Keywords Education policy · International cooperation · Governance · Quality · Globalization

Throughout the world, many international organizations are exercising a growing influence over education policies. Since World War II, a historical and geographical distribution of the roles of the various organizations has emerged. UNESCO, UNICEF and the World Bank are very influential in education policies in the countries of the South. The OECD has long guided education reforms in the countries of the North. But this distribution evolved as the world gradually came to be seen as divided according to its level of economic development. Given more recent developments, is it still valid today? Emerging countries, such as China and Brazil, appear to be resisting this traditional classification of areas of influence. The high-level results of the Province of Shanghai in the recent OECD PISA

A. Akkari · T. Lauwerier ( $\square)$

University of Geneva, Bd du Pont d'Arve 40, 1205 Geneva, Switzerland

e-mail: thibaut.lauwerier@unige.ch

A. Akkari

e-mail: abdeljalil.akkari@unige.ch 
surveys argue in favour of greater flexibility in analyzing the influence of international organizations.

We chose to look at international organizations (IOs) as essential actors in education policy for two main reasons. First, given their preponderant financial weight, they play significant roles in guiding education policy. That is particularly true in the case of the World Bank and UNICEF, which inject substantial financing into education systems. Moreover, as resources for good education practices, benchmarking, and tools for evaluating education policies, these organizations also wield influence through their expertise.

In the first section of this article we describe the main characteristics of the IOs that are active in the field of education, and show how their policies have developed over the past two decades. In the second section we explain the common concepts and tools these organizations use to influence education policy. In the third section we address possible alternatives to their prevailing policies.

The article is mainly based on our examination of the official reports of the World Bank, OECD, UNESCO and UNICEF between 1990 and 2000, as well as a secondary analysis of existing literature on this subject. We also take into account some recent in-depth research on the influence of these organizations (Lauwerier 2013). From a theoretical viewpoint, we have followed a dynamic and interactive approach in analyzing education policies, and particularly the role of international cooperation. We believe that the orientations of these organizations are not set in stone and that they evolve over time, in accordance with geographical contexts and through contact with a variety of national and international actors. Most studies analyzing the role of international cooperation still tend to give the impression that the organizations concerned have maintained their specific qualities, especially the World Bank's neo-liberal agenda and UNESCO's humanist vision. However, more and more studies, although still isolated, are emphasizing that the policies of such organizations are tending to converge (Abadzi 2012; Cerqua and Gauthier 2013; Wiseman 2010). In this article, we are emphasizing this evolution, as it appears to be a major factor in education at the international level.

\section{International organizations that influence education policies}

The IOs that are influential in the field of education have their own specific histories. This makes it useful to first review the contexts within which they, and their missions, emerged.

\section{United Nations Educational, Scientific and Cultural Organization (UNESCO)}

Created in 1945 following World War II, UNESCO is the United Nations agency specializing in education. It played a preponderant role in providing support to newly independent Asian and African countries as they developed their education systems in the decade 1950 to 1960 . From the outset, UNESCO placed a priority on the core functions of education: decolonization, development; promoting human rights, access to education and literacy; and safeguarding each country's cultural heritage.

Our analysis of UNESCO's institutional texts shows that its policies evolved progressively between 1990 and 2010. During the last decade of the 20th century, UNESCO maintained its historical policy orientation, based on its vision of education focused on the right to education. The World Conference on Education for All in Jomtien in 1990, held as a joint initiative with other IOs, and particularly the World Bank and UNICEF, also had the objective of making primary education universal and radically reducing illiteracy before the end of the decade. The Delors report (1996) offers a sound synthesis of UNESCO's 
historical position in relation to education policy and was a key document in conceptualizing education as defined by the principles of lifelong learning and the four pillars of learning: learning to be, learning to know, learning to do, and learning to live together.

The key event in the first decade of the $21^{\text {st }}$ century was the 2000 World Education Forum held in Dakar. Attendees called on governments to develop education policies aimed at improving the quality of basic education for all, and particularly for girls. Three dimensions - equitable access, the quality of basic learning, and the relevance of learning — had been put forward in Jomtien in 1990. By 2000, they had gradually been reduced to two dimensions: equitable access and the quality of basic education. A few months after the Dakar Framework for Action was approved, UNESCO adopted the Millennium Development Goals (MDGs), which carried more weight than other frameworks. This process resulted in a more restricted vision, focused mainly on primary education, which would serve as a reference for the international community (Tawil 2013).

During that period, UNESCO's philosophy with regard to education was reflected in the regular Education for All (EFA) Global Monitoring Reports, for which UNESCO acts as the secretariat. These regular reports are intended to review progress in achieving Education for All and focus on priority areas: gender in 2003, quality in 2005, literacy in 2006, early childhood in 2007, governance in 2009, marginalization in 2010, armed conflict in 2011, youth, skills, and work in 2012, and teaching and learning in 2013-14. While UNESCO opted for themes that emphasize the primacy of learning, as well as quality and skills, it maintained its traditional policies, including the right to education and the reduction of inequality. In this respect, literacy acts as a unifying theme, one that presupposes that access to education will develop simultaneously with the quality of learning. It is important to note that access, equity and quality are inseparable dimensions of education. In other words, emphasis should be placed on the equitable access of all to relevant learning.

Starting in the 2000s, however, UNESCO documents (UNESCO 2000, UNESCO OREALC 2008) began to reveal a gradual shift away from these interests and towards the evaluation of learning outcomes. The issue of evaluation was not entirely new, since it had already emerged in 1990 during the Jomtien conference. If the quality of education is to be addressed seriously, UNESCO has been suggesting, increasingly specifically, it is important to be able to offer a clear definition and measurement tools. According to UNESCO, countries wishing to uphold the right to basic education for all need to be able to determine the knowledge and know-how that constitutes such education. They need a certain level of technical and organizational capacity in order to evaluate the learning outcomes of students in accordance with set standards, and to assess the way that school systems are fulfilling their mission (UNESCO 2000, p. 8).

In short, it appears that UNESCO is taking a less and less visible position in relation to education. It does not seem to have either the means or the technical expertise to act at the global level within individual countries. The vagueness of UNESCO's real mandate persists, as indicated by a former UNESCO official:

Thus far, we have established that UNESCO does not respond well to the demands from its education ministry and minister clients but does respond to the broader political demands from its client member states. Indeed the latter is the major explanation of the former. But UNESCO's problems in providing global public goods in education go much further. There is no real agreement on its priorities, its governance is cumbersome and very demanding on the staff, its budget is inadequate, its staff are not all appropriate, and there is not an effective collaboration with its partners/competitors. (Burnett 2010, p. 93) 


\section{United Nations Children's Fund (UNICEF)}

UNICEF was established in 1946 as a United Nations emergency fund to provide assistance to children who were severely affected by World War II. We should point out that, though both UNESCO and UNICEF are part of the United Nations system, they do not have the same status. UNICEF is a fund, while UNESCO is a technical agency. That means that UNICEF can seek funding to finance its own activities, but UNESCO remains subject to the goodwill of its member states and depends on their paying their contributions.

At the end of the 1980s, UNICEF played a central role in the United Nations adoption of the Convention on the Rights of the Child on 20 November 1989. UNICEF stood out for developing a series of international conventions for children and regular international campaigns to ensure that children's rights to protection and education were central to public policy concerns.

During the 2000s, UNICEF anchored its strategy more fully in advocacy, while positioning itself as the organization promoting "child-friendly schools" (UNICEF 2009; Wright 2009). The aim was to mobilize donors, states and private actors, as well as citizens, in favour of basic education. Since the end of the 2000s, UNICEF has made a significant strategic change in the field of education. Previously focused on support at the school level (distributing supplies, encouraging "child-friendly schools" and community participation in school management, understanding and countering violence at school, etc.), its position in the sector is now much further upstream at the strategy and policy levels. Still, it remains very active in the field in emergency and conflict situations and plays a central role in the education clusters that are established in such situations.

The change in UNICEF's policies over the past two decades can be observed in its regular reports. Its flagship publication is its annual State of the World's Children report, which provides the most recent statistics on the survival, development and protection of children throughout the world. Over the past two decades, UNICEF policies have focused on constant action to help the most vulnerable children based on their gender, social status, disability, ethnic origin or war situation.

In its education strategy, UNICEF (2012) emphasizes the need to help marginalized and poor populations. In a knowledge-based world, UNICEF believes education represents the best investment that a country can make to develop prosperous, healthy and equitable societies. From this perspective, education is instrumental in helping people achieve their optimal potential and in improving the means of existence of current and future generations. It is also important to go beyond the instrumental benefits of education by proposing learning opportunities for all. This view is based on the conviction that a good education is the right of each child in every country. Poverty, sex, ethnicity and geography should not deprive a child of a decent education (UNICEF 2012).

With a view to making the commitment of the international community to basic education more dynamic, the United Nations, with the support of UNESCO and UNICEF, has recently launched the Education First initiative, based on three priorities: expanding access to education, improving the quality of learning and fostering global citizenship. If it is to succeed in making a crucial breakthrough in education, according to UNICEF (2012), this initiative will have to succeed in three areas: 
1. Rally a broad spectrum of actors for the final push to 2015 , to ensure we deliver on the promise of universal access to primary education.

2. Spur a global movement to put quality, relevant and transformative education right at the heart of the social, political and development agendas.

3. Generate additional and sufficient funding for education through sustained global advocacy efforts.

UNESCO (2009) appears to have maintained its traditional priorities in the field of education with recurrent themes, such as the education of girls and of the poor. Thanks to a fund it administers, UNICEF has maintained a strong presence in the field in building schools and distributing textbooks and teaching materials. The recent Education First initiative also shows that it has maintained its power to exercise significant influence over other IOs.

\section{The World Bank}

Founded in 1945, the World Bank has been engaged in financing development projects, particularly in infrastructure (dams, roads, mines, etc.). It may currently be considered the main international actor financing education; in addition, and almost more important, it has the resources and capacity to analyze and provide expertise on education policies (Bourdon 2002). In the 1960s, the Bank began to invest in vocational training programmes based on the demand for skilled labour. Then, in the 1980s, in response to criticisms that it was only engaged in vocational and technical training, it extended the scope of its financial investments to include all levels of education, from pre-primary to higher (Heyneman 2003).

Since the 1960s, the organization has based its policies on the theory of human capital, which sees education as an instrument of economic growth. It addresses the education system in terms of inputs and outputs. The rate of return of the various levels of education was the priority instrument in determining adequate investment in education (Bennel 1996).

The period 2000 to 2010 saw the Bank changing direction. It began to take more interest in the role education could play in policies for the poor, and in measuring learning and its quality (Cling, Razafindrakot, and Roubaud 2002; Vegas and Petrow 2007). It holds that acquiring basic knowledge and skills is key to reducing poverty in the world:

Basic knowledge and skills—not educational attainment—are key to reducing poverty. Raising enrollments and completing primary schooling are necessary-but not sufficient — to ensure basic literacy and numeracy. (World Bank 2006, p. xiii)

Therefore, the Bank appears to be convinced that, though it is essential to expand access to schooling, that expansion has occurred at the expense of improvements in learning. It will be possible to avoid a trade-off between improved access and learning gains by explicitly planning to improve learning outcomes and making a strong political commitment to that goal. If the rates of primary school completion rise because schools automatically promote children to the next grade without heeding their learning outcomes, then those higher completion rates will not reflect improvement in knowledge and skills-which is the ultimate policy objective. In particular, those improvements will not occur among the disadvantaged. Bank analysts consider that many of the strategies used to increase access rapidly, such as fee reductions, use of contract teachers, double-shifting and automatic promotion, have had negative effects on learning outcomes, at least in the short term, even though it was promoting these strategies in the 1990s. Moreover, some of these strategies are difficult to sustain (World Bank 2006). 
The Bank also aims to expand learning opportunities outside school:

Past education strategies of the World Bank have focused very much on formal schools that are funded and/or operated by governments. The new strategy explicitly recognizes that learning opportunities go beyond those offered by the public sector, as well as beyond traditional formal programs. Critical learning activities are available outside of formal schooling, such as before the 'official' age of school entry or after a young person has left school. (World Bank 2011, p. 34)

In the Bank's strategy, learning is not related to the number of years spent in school, but to what the student has learned:

The new strategy focuses on learning for a simple reason: growth, development, and poverty reduction depend on the knowledge and skills that people acquire, not the number of years that they sit in a classroom. At the individual level, while a diploma may open doors to employment, it is a worker's skills that determine his or her productivity and ability to adapt to new technologies and opportunities. (World Bank 2011, p. 3)

This is a notable development in World Bank thought on basic education. For many years, the Bank had based its action in the education sector on a calculation of the rate of return of primary and secondary education. However, this calculation focuses on the number of years a person spends in school and the wages that person can theoretically earn in relation to that schooling.

Although the Bank has not abandoned its leitmotiv of education being absolutely fundamental to development and growth, in its latest reports it has referred to education as a basic human right enshrined in the Universal Declaration of Human Rights and the United Nations Convention on the Rights of the Child. It adds that the human mind makes possible all other development achievements, from advances in health and agricultural innovation to the construction of infrastructure and private-sector growth. For developing countries to reap these benefits fully, both by learning from the stock of global ideas and through innovation, they need to unleash the potential of the human mind. And there is no better tool for doing so than education (World Bank 2011, p. xi).

The Bank's contacts with education in the countries of the South have led it to progressively abandon the orthodoxy of its initial policies based solely on rates of return (Bennell 1996; Lauwerier 2013). Menashy (2007), however, considers that, for most of the 1990s, the essential criticism of the Bank was directed at its neo-liberal mandate, which was reflected in various measures in education. Moreover, while it maintained a certain autonomy, it has been increasingly involved in multi-donor programmes, with common reference frameworks, and particularly those arising out of Education for All and the Millennium Development Goals. The Bank has had to integrate these new approaches into its action (World Bank 2006, 2011).

Thus, in its rhetoric and initiatives it appears to have recently distanced itself from this initial ideological position to a remarkable extent. But Klees (2002) sees only a new rhetoric based on an old ideology, and Zoundi (2008) shows that its education policies are in conformity with the neo-liberal ideology and a reductionist and utilitarian vision of human capital in which girls and women are considered to be an essential resource for production, one that must not be wasted (Table 1).

Organization for Economic Co-operation and Development (OECD)

While UNESCO, UNICEF and the World Bank have had an important influence on designing education policies in the countries of the South, the OECD has had a growing 
Table 1 Evolution of the World Bank's priority education strategies

\begin{tabular}{|c|c|c|c|}
\hline & 2000 & 2005 & Leading up to 2020 \\
\hline Goals & Quality Education for All & $\begin{array}{l}\text { Education for All and } \\
\text { education for the } \\
\text { knowledge economy }\end{array}$ & Learning for all \\
\hline Priorities & $\begin{array}{l}\text { Basic education (for the } \\
\text { poor, girls) } \\
\text { Early interventions } \\
\text { (development of young } \\
\text { children, school health) } \\
\text { Innovative experiments } \\
\text { Systematic reform }\end{array}$ & $\begin{array}{l}\text { Integration of education } \\
\text { into the national } \\
\text { outlook } \\
\text { Adoption of a sectoral or } \\
\text { holistic approach } \\
\text { Results-based education } \\
\text { policies }\end{array}$ & $\begin{array}{l}\text { At the country level, strengthening } \\
\text { education systems to achieve } \\
\text { results } \\
\text { At the global level, developing a } \\
\text { high-quality knowledge base on } \\
\text { education systems }\end{array}$ \\
\hline
\end{tabular}

influence on the countries of the North. This importance is reflected less in terms of financial commitments, and more in the stimulation of education policies and international comparative studies. Given the nature of its mandate as an IO aimed at economic development, the OECD was the first one to place skills development at the centre of its priorities. At the ideological level, the OECD is close to the World Bank, even though their policy orientations are not always similar. For example, while the Bank talks about privatizing education, the OECD supports demand-sensitive schooling (OECD 2006) and raises more questions concerning the real benefits of private schools (OECD 2011).

During the decade of the 1990s, the OECD was principally interested in lifelong learning. This interest likely stemmed from the economic restructuring that marked the transition from economies based on the secondary industrial sector to those based on the tertiary sector (Vinokur 2003).

During the decade 2000 to 2010 , the OECD focused its interest on the indicators needed to guide education policies. This period also saw the beginning of the regular comparative surveys of the OECD Programme for International Student Assessment (PISA), intended to test students at age 15 to determine if they have acquired the skills and knowledge they need for everyday life once they have completed compulsory schooling. According to the OECD (2012a), skills have become the global currency of the 21st century. Without proper investment in skills, people languish on the margins of society, technological progress does not translate into economic growth and countries can no longer compete in an increasingly knowledge-based global society. Accordingly, if students in the OECD area were to raise their performance by the equivalent of spending just one more semester in school, that would add US \$115 trillion to the area's economy over the working life of the generation born that year. But this "currency" of skills can depreciate as the requirements of labour markets evolve and individuals lose the skills they do not use.

Moreover, the OECD (2012a) sees a clear message in the coexistence of unemployed graduates and employers who cannot find employees with the skills they need. Skills do not systematically translate into higher earnings and productivity. To ensure that skills are placed at the service of better jobs and lives, a sounder understanding is needed of the skills which improve our lives and economies. Governments therefore have to upgrade the collection and use of information so that they can anticipate changes in the demand for skills. They need to cooperate more closely with enterprises as they plan and implement school and training programmes. Skills development is much more effective if the world of learning is linked to that of work. Training at the workplace introduces young persons to a professional environment and enables them to acquire technical skills as they work with 
modern equipment, as well as the general skills that come with first-hand experience. Practical training also strengthens the motivation and engagement of young persons who have left school, and thus facilitates their transition to the labour market (OECD 2012a). The OECD places a priority on education that serves the economy and allows people to develop skills they need for employment.

Equity is the other principal objective of the OECD. According to the OECD, education policies based on equity can play an essential role in reducing income inequality. OECD research shows that a more equitable distribution of education opportunities typically results in a more equitable distribution of income from labour. It is also clear that people with higher levels of education have a significant competitive advantage on the labour market in both good and bad economic periods. Education policies which emphasize equity, and help both disadvantaged and advantaged students to achieve strong academic outcomes, continue onto higher levels of education, and eventually secure good jobs, could therefore foster greater intergenerational earnings mobility and reduce income inequality over time (OECD 2012b).

The results of the PISA assessment demonstrate the potential of this type of approach. For example, the 2009 reading assessment showed that Canada, Finland, Japan and the Republic of Korea were all among the top performers. In each of these countries, the strength of the relationship between the performance of students and their socioeconomic background was below the OECD average. However, these countries have something else in common: their education systems focus strongly on equity. From a policy perspective, they endeavour to provide high-quality education to all students and to minimize broad variations in school performance through an equitable distribution of resources (OECD 2012b).

Finally, as Breakspear (2012, p. 4) indicates, a recent OECD study on the global effect of PISA concludes that it "has become accepted as a reliable instrument for benchmarking student performance worldwide".

\section{Dominant concepts and instruments}

Our analysis of the organizations' policy orientations suggests that since 1990 their education policies have been subject to a series of dominant concepts that therefore merit discussion: quality, good governance and accountability, privatization, benchmarking and the measurement of learning outcomes. All of these concepts are interrelated and make up the conceptual stock into which international organizations and governments dip for the ideas that will guide and pilot their education policies.

\section{Quality}

While it is hard to deny the importance of quality in education, it is not easy to find a satisfactory definition or reliable instruments to measure it (Tawil, Akkari, and Macedo 2012). International organizations have gone further into the subject of the quality of basic education following the substantial improvement in the access of children to primary education throughout the world. The EFA Global Monitoring Report 2005 (UNESCO 2004) offers an adequate framework for analysis to address the issue of the quality of basic education. According to this framework, the quality of education depends on four parameters: learner characteristics and aptitude, enabling inputs for learning, the school context and the outcomes of the learning process. 
The framework UNESCO used is very close to that of the World Bank (2006), though the latter is more focused on the school factor (Heneveld and Craig 1995). For both documents, Tikly (2011) refers to an overly technical approach that does not sufficiently consider the contexts and aggravating factors of inequality. UNICEF's approach to quality focuses on the issue of human rights; it places a priority on the learner as central to the education process (UNICEF 2007).

Despite the efforts of researchers and IOs, especially UNESCO, the quality of education continues to be conceptualized as a matter of figures and indicators. Indeed, it is addressed solely from a quantitative perspective, particularly when researchers are making comparisons between countries. Most models for analyzing the quality of education schematize the education system into three interrelated spheres, with the sphere of the learning and education process at the centre (Heneveld and Craig 1995; UNESCO 2004; UNICEF 2007). The first sphere includes inputs into the system, and finds expression in access to education. The third sphere contains the outputs, which are measured in terms of the knowledge and skills that learners acquire. In theory, the quality of education is situated in the middle "process"/sphere, although it is also influenced by the other two spheres.

It may therefore be observed that most of the instruments used to measure and assess quality are based on quantitative indicators. This is very clear in the case of the OECD, which, for example, measures the outcomes of standardized tests in classes with a view to comparing them. In other words, thinking of quality as something that can only be evaluated using quantitative measures has led people to see qualitative tools as less valid. And yet, the social, economic and cultural relevance of the knowledge that students acquire is also key to assessing education quality.

\section{Good governance and accountability}

Concern for good governance is based on the hypothesis that many education systems have been badly administered. Yet one can hardly claim that other sectors of public policy have been better managed: consider the example of corruption in global financial and economic governance. And we should emphasize that states have made considerable progress in ensuring compulsory education for children of specific age groups. We are all aware of recurrent problems related to the excessive centralization of education and to corruption, but still we find it simplistic to claim that good governance is the key to making education policies succeed. Can good governance compensate for inadequate financing of public education or for dilapidated infrastructure? Nevertheless, this concept is increasingly finding its place in the discourse of IOs.

In relation to governance, the World Bank is particularly concerned by the lack of institutional capacity, especially among medium- to high-level officials in ministries of education, and by the phenomenon of corruption:

A governance issue that poses a fundamental threat to education outcomes is corruption. It is essential that sector assessments identify both the problem-whether it occurs outside the education sector (buying and selling of civil service jobs) or inside (buying and selling of grades or admission to preferred schools)—and the options for remedy. (World Bank 2005a, p. 36)

UNESCO has also become interested in the issue of governance, to which it devoted a full report (UNESCO 2008). And UNICEF, in its Education Strategy 2006-2015, sets out the concept of good governance as a primary requirement for more effective action, which it nevertheless relates to the issue of respect for children's rights (UNICEF 2006a). It is 
noteworthy that the OECD (2010) also recommends that member states (countries of the North) adopt "good governance practices", as it is governments which design standards and set policies.

Good governance is generally seen as a parallel to the notion of accountability, which involves holding all the actors in the education system accountable for the effects and practices of their actions. In education, accountability especially affects education administrators, teachers and schools. It is an important tool in ensuring that education systems make the transition from a logic of resources to one of processes and outcomes. And it is important to consider who is being asked to be accountable. IOs often develop tools related to bureaucratic accountability (OECD 2013), but the accountability of teachers is also crucial, as they must be committed to and have a sense of responsibility towards learners.

The World Bank is so attached to accountability that it has established an evaluation system, the Systems Approach for Better Education Results (SABER), to ensure that accountability is fully considered in national education policy (World Bank 2011).

Although accountability had not previously been central to its concerns, UNICEF (2006a, p. 4) recommends as a priority that "education systems are accountable, well managed".

Finally, in 2005, a UNESCO researcher challenged governments' unsound management of education systems:

As the economies of nations compete for strong positions within a competitive global marketplace, many governments have become increasingly interested in the performance of all aspects of their education systems. This trend, coupled with the enormous expenditures that are devoted to education, has also precipitated widespread public requests for higher levels of scrutiny concerning the quality of education. These demands for information about school system performance can only be addressed through the implementation of systematic accountability systems. (Anderson 2005, p. ii)

UNESCO (2008) nevertheless remains cautious on this point; along with De Grauwe and Lugaz (2007), it recalls that insisting on decentralization or local accountability could in practice exacerbate inequalities rather than reducing them.

\section{Privatization}

Certain IOs, mainly the World Bank, appear to regard privatization as a miraculous solution to a range of education problems, though they do acknowledge certain limitations, such as the potential increase in inequality. In particular, they believe that diversifying the supply of education by developing private operators can in itself guarantee an overall improvement in education. However, this vision is simplistic, not only because education does not in itself constitute a real market, but also because almost everywhere throughout the world, at the various levels of education, the boundaries between public and private are blurred (Akkari, Pompeu, Fernandes Costa, and Mesquida 2011; Ball and Youdell 2007).

The World Bank (2005a, p. 5) affirms its desire for privatized systems by proposing that education should enjoy "active community and private sector involvement". It justifies greater privatization in the following terms:

In some countries parents are increasingly expressing a demand for improved educational quality by enrolling their children in private schools, which they perceive to have 
higher standards than public schools. School surveys in Ghana showed an increase in private primary school enrolments from about 5 percent of the total in 1988 to more than 20 percent in 2003. In Mali, private school enrolments plus those in community schools - those sponsored by nongovernmental organisations (NGOs) and community groups-grew to about 25 percent of the total in 2003. (World Bank 2005a, p. 27)

Although the Bank's commitment to privatizing education would appear to be steadfast (Lewis and Patrinos 2011; Sosale 2000), that does not mean that it supports marginalizing the role of the state. Accordingly, the Bank's position is that, while governments must contribute substantially to financing the compulsory phase of secondary education, families and communities should play more active roles in financing post-compulsory education. This is where public-private partnerships can contribute to providing mass secondary education at an attainable price (World Bank 2005b). Moreover, the 2005 Strategy Update (World Bank 2005a) highlights several changes since the previous (1999) report. And, while the 1999 report promoted user fees, the 2005 report recommends eliminating them at the primary level.

Since the 1990s, the OECD has thought it necessary to review public management, which has not always been effective in generating reforms in the education sector. Therefore, it recommends greater flexibility in exploring alternatives to public investment and regulation which it believes would result in more cost-effective policy outcomes (OECD 1995).

UNICEF and UNESCO are less interested in seeing education systems privatized. They see the need to respect the fundamental right to education, which requires free and public education. Still, their approach appears to have evolved over recent years, as they are also envisaging public-private partnerships (UNICEF 2010). They have also noted the limitations on public resources. In addition to free education, they see other strategies as necessary to achieve universal high-quality education. In this context, solutions involving the private sector, schools, partnerships, and innovative forms of financing are now emerging as possible alternatives (UNESCO IIEP 2012, p. 9).

Strongly performing education systems: Benchmarking and measuring outcomes

Benchmarking, the use of comparative studies based on target values, is intended to identify good education practices and incorporate them into education policies in order to improve performance. The World Bank and the OECD often use this technique, which originated in the world of business: identifying "best practices" and advocating their transfer from one education context to another. However, despite its potential, this technique underestimates how much education systems are historically and culturally anchored in a specific context. The borrowing of good practices in education policy is resulting in a common transnational agenda:

This agenda,... defines education primarily in terms of its economic value and learners as human resources, required by the global production system. In the beginning of the twenty-first century, we are experiencing, at the most official level, not only the transnationalisation of education policy making but also the subjugation of education to the mandates of the global economy. (Moutsios 2009, p. 479)

The latest of the dominant concepts, related to benchmarking, concerns the measurement of learning outcomes. Clearly, this does not mean educators evaluating their impact on their own students. Here, measurement means evaluating students, schools, teachers and education systems based on standardized tests administered on a broad scale. Once again, the final objective is to identify the school models that perform most strongly. 
More precisely, the World Bank uses target values (or benchmarks) to improve the performance of education systems by taking as models the countries it sees as having succeeded the best economically. In general, these are emerging Asian countries. That practice very often leads to teachers being paid less, and fewer students repeating grades (Altinok 2005, p. 21). Bourdon (2006) describes the World Bank's model of strong performance as possessing the five characteristics listed below. It urges the countries it considers to be underperforming to emulate these practices.

1. They allocate a large part of the national budget to primary education.

2. Their unit costs are within the average of the countries examined - neither too high nor too low.

3. They pay the average teacher at around 3.6 times the GDP per capita.

4. A large part of expenditure is on non-recurrent purchases (generally non-wage costs).

5. The average teacher has about 40 students, and their average repetition rate is below $10 \%$.

From the same perspective, PISA enables the OECD to legitimize and standardize the evaluation of national education systems. Indeed, as its tests have come to enjoy global popularity, they have made the OECD an expert in international evaluation. In practice, this acts as pressure for countries that closely follow the publication of PISA results, hoping for improvements. For example, the OECD (2010, p. 10) congratulated Mexico in the following terms: "the performance gains that Mexico has achieved since President Calderon established the PISA performance target have been significant". Indeed, Mexican students' scores rose from an average of 392 points in 2003 to 435 in 2010.

UNESCO uses data from the Programme on the Analysis of Education Systems (PASEC) of the Conference of Ministers of Education of French-speaking Countries and of SACMEQ, the Southern and Eastern African Consortium for Monitoring Education Quality. It recognizes the need to evaluate African education systems by comparing certain indicators (skills acquired at school, level of teachers, etc.) in order to finally achieve strongly performing systems (Bourdon and Nkengné-Nkengné 2007). These results have served as a basis for discussing education policies. By the end of the 1990s, UNESCO and UNICEF had already jointly designed and launched measurements of basic learning and life skills in a number of countries through a programme called Monitoring Learning Achievement (MLA) (UNESCO 2000).

While UNESCO (2007) and UNICEF (2006b) place more emphasis on the contexts and needs of learners, they do not hesitate to use the concept of best practices to identify education measures that have succeeded and should be used as sources of inspiration.

\section{What are the alternatives?}

Our analysis shows a certain convergence that unites these organizations beyond their specific policy directions.

For example, UNICEF and UNESCO continue to give priority to a rights-based approach to education. According to one of their reports (UNICEF/UNESCO 2007), such an approach adds significant value to education for six reasons:

- It promotes social cohesion, integration and stability.

- It builds respect for peace and non-violent conflict resolution.

- It contributes to positive social transformation.

- It is more cost-effective and sustainable.

- It produces better outcomes for economic development.

- It builds capacity. 
Nevertheless, UNICEF did not hesitate to publish, with the World Bank, a report on the costs of education (school fees), thereby demonstrating its flexibility (World Bank/UNICEF 2009). Although all of the four organizations we analyzed are receptive to the dominant concepts, it can be seen that the World Bank and, to a lesser extent, OECD are the two drivers in this field. UNESCO appears to be the most hesitant and UNICEF occupies a middle position. Therefore, it is interesting to note that over the course of time the influence of these organizations has varied and that, depending on the period, some have been more capable than others of influencing international debate, and thereby national education policies.

Mundy (2006) has shown that the EFA movement is the result of a "progressive rapprochement" between two apparently opposed paradigms: the neo-liberal and proeconomic approaches approved by the International Monetary Fund (IMF) and the World Bank in the 1980s and 1990s, and the approaches of equity and skepticism towards globalization adopted by the United Nations system. Accordingly, since the 1990s, a global third way has been emerging. As the activities of various IOs often overlap in the field, Burnett (2010) correctly points out the need to review the global architecture of the IOs responsible for education. Thus, we see an urgent need for UNESCO, UNICEF, the World Bank, and the OECD to reach agreement on how they will share their responsibilities, both in managing knowledge and in working at the country level, while at the same time avoiding the excesses of a mainstream approach with neo-liberal tendencies.

However, while our analysis points to greater complexity in this sense of overall convergence, it also suggests an underlying tension between the two essential functions of an international organization such as UNESCO. One function is more intellectual and truly global, and the other is more technical, as a development agency. These two functions, both within its mandate, have completely different implications in terms of discourse, justification, priority areas of action and types of activities and partners. For example, while the intellectual institution of UNESCO engages in reflection concerning all the regions of the world and the education system as a whole, including lifelong learning, the technical agency is more specifically interested in basic education in the low-income countries of the South (Tawil forthcoming).

Moreover, UNESCO is not acting in a vacuum, and comes into contact with a diverse range of national and local actors. Certain partners try to make use of its influence to call for an acceleration of neo-liberal education reforms; others resist, pointing out that international comparative studies have methodological limits and can be incoherent. For all these reasons, we believe it is useful to reflect on the policy alternatives that may be able to counter the dominant orientations of IOs, or at least stimulate debate about them. Indeed, UNESCO and UNICEF are currently engaged in reflection along these lines.

We see these alternatives as revolving around three principal concerns: (1) education as a right and a public good; (2) the relevance of education as a priority for public policy; and (3) the reduction of inequality (Klees, Samoff, and Stromquist 2012; UNESCO 2013).

Education as a right and a public good

Given the multiple attempts to circumscribe the role of schools and treat education as an instrument in the service of the economy, it is necessary to confirm that education is a fundamental human right. As Charlot (2002) emphasizes, education is a triple process of humanization, socialization and singularization. Of course, education contributes greatly to the economy, and standardized tests do have some legitimacy. But as Sen (1999) 
points out, we must recall the value that schooling has in terms of membership of society, development, and individual and collective freedoms.

If education is considered to be a public good, then the state has a particular and primary responsibility in this field. Even though families and NGOs can participate in managing education, the principal responsibility lies mainly with the state and its public services. Simply diversifying the supply will not remove the obstacles to children accessing good quality basic education. And states play an imperative and unavoidable role in unstable regions in the global South, where the failure of the state may lead certain IOs or NGOs to try to replace it.

The relevance of education

Over the past decade, education policies have been increasingly focused on the essential issue of the quality of education and the measurement of learning. This focus on quality may seem logical, given the strong focus on the problem of access during the 1990-2000 decade. However, the dominant approaches to quality have been exclusively based on measurable and quantifiable dimensions. Thus, we point to the relevance of education as an alternative to the quality of education. Education must be relevant for several reasons:

- It facilitates improved membership in society, along with freedom and participation.

- It allows students to acquire useful skills and knowledge for everyday, professional, school and social life.

- Relevant education serves humanity as a whole, through society, local communities, and the family.

- Relevant education allows people to gain access to a life of dignity, a critical spirit, and autonomy.

However, the relevance of education must not be reduced to its socio-economic dimension. It encompasses the whole potential and capacity of learners (Barrett and Tikly 2012).

The reduction of inequality

Many researchers have found that education is a precious good that is unevenly distributed between countries and, within countries, between people in various social categories. In addressing inequalities between countries, international cooperation may be an appropriate tool to reduce the North-South divide. Within each country, reducing inequality will require redistributing material and cultural resources, and ensuring social mixing between the various socio-cultural groups.

In conclusion, we have demonstrated the need to analyze, in depth, the role that IOs play in developing education policies. These roles have changed continuously, as the organizations and the international development cooperation agenda have evolved, and as experts in knowledge, innovation and education have spread throughout the world. These organizations wield influence that can be decisive in breaking down barriers between education systems and in transferring vital experience. But this influence can be harmful if it is confined to a utilitarian and limited conception of education. 


\section{References}

Abadzi, H. (2012). Global panaceas, local realities: International agencies and the future of education. International Review of Education, 58(2), 301-302.

Akkari, A., Pompeu, C., Fernandes Costa, A. S., \& Mesquida, P. (2011). Construction historique d'un système éducatif dual et brouillage actuel des frontières entre les réseaux scolaires public et privé au Brésil [History of the construction of a dual education system and blurring of the borders between public and private school networks in Brazil]. Autrepart, 59, 109-124.

Altinok, N. (2005). La Banque Mondiale et l'éducation en Afrique subsaharienne: Analyse normative du meilleur système éducatif: Institutions et développement [The World Bank and education in subSaharan Africa: Normative analysis of the best education system: Institutions and development]. Dijon: IREDU-CNRS.

Anderson, J. A. (2005). Accountability in education. Paris: UNESCO IIEP.

Ball, S. J., \& Youdell, D. (2007). Hidden privatisation in public education. Brussels: Education International.

Barrett, A. M., \& Tikly, L. (2012). Quality in education from an international perspective. Bristol: EdQual.

Bennell, P. (1996). Using and abusing rates of return: A critique of the World Bank's 1995 education sector review. International Journal of Educational Development, 16(3), 235-248.

Bourdon, J. (2002). La Banque Mondiale et l'éducation ou est-il plus simple de construire de grands barrages que de petites écoles? [The World Bank and education, or is it simpler to build large dams than small schools?]. Dijon: IREDU, University of Bourgogne.

Bourdon, J. (2006). Coût et financement de l'éducation primaire en Afrique subsaharienne [Cost and financing of primary education in sub-Saharan Africa]. In J. B. Pilon \& M. Pilon (Eds.), Défis du développement en Afrique subsaharienne: L'éducation en jeu (pp. 123-145). Paris: CEPED.

Bourdon, J., \& Nkengné-Nkengné, A. P. (2007). Les enseignants contractuels: Avatars et fatalités de l'éducation pour tous [Contractual teachers: Misadventures and fatalities of education for all]. Presented at the seminar "La professionnalisation des enseignants de l'éducation de base: Les recrutements sans formation initiale". In Proceedings of the CIEP international seminar, 11-15 June 2007, La Professionnalisation des Enseignants de L'éducation de Base: Les Recrutements sans Formation Initiale. http://www.ciep.fr/sources/conferences/CD_professionnalisation/bak/pages/docs/pdf_interv/ Bourdon_Nkengne.pdf.

Breakspear, S. (2012). The policy impact of PISA. OECD education working paper no. 71. Paris: OECD.

Burnett, N. (2010). How to develop the UNESCO the world needs: The challenges of reform. Journal of International Cooperation in Education, 13(2), 89-99.

Cerqua, A., \& Gauthier, C. (2013). La qualité de l'éducation dans le discours des organisations internationales: Exigences du point de vue de la professionnalisation de l'enseignement [The quality of education in the discourse of international organisations: Requirements from the perspective of the professionalisation of teaching]. Initio, 3, 26-44.

Charlot, B. (2002). Education et cultures [Education and culture]. VEI Enjeux, 129, 137-145.

Cling, J.-P., Razafindrakot, M., \& Roubaud, F. (2002). La Banque mondiale et la lutte contre la pauvreté: Tout changer pour que tout reste pareil? [The World Bank and poverty reduction: Changing everything so that everything remains the same?]. Paris: DIAL.

De Grauwe, A., \& Lugaz, C. (2007). Décentralisation de l'éducation en Afrique francophone de 1'Ouest: Réalités et défis au niveau local [The decentralisation of education in Western Francophone Africa: Local-level realities and challenges]. International Review of Education, 53(5-6), 613-638.

Heneveld, W., \& Craig, H. (1995). Schools count: World Bank project designs and the quality of primary education in sub-Saharan Africa. Washington, DC: World Bank.

Heyneman, S. P. (2003). The history and problems in the making of education policy at the World Bank 1960-2000. International Journal of Educational Development, 23, 315-337.

Klees, S. J. (2002). World Bank education policy: New rhetoric, old ideology. International Journal of Educational Development, 22, 451-474.

Klees, S. J., Samoff, J., \& Stromquist, N. P. (Eds.) (2012). The World Bank and education: Critiques and alternatives. Rotterdam: Sense Publishers.

Lauwerier, T. (2013). L'influence de la Banque mondiale sur les politiques nationales d'éducation de base en Afrique de l'Ouest francophone [The World Bank's influence on national basic education policies in French-speaking West Africa]. Geneva: FAPSE, University of Geneva.

Lewis, L., \& Patrinos, H. A. (2011). Framework for engaging the private sector in education. Washington, DC: World Bank.

Menashy, F. (2007). World Bank educational policy: Do the neoliberal critiques still apply? McGill Journal of Education, 42(1), 47-60. 
Moutsios, S. (2009). International organisations and transnational education policy. Compare: A Journal of Comparative and International Education, 39(4), 469-481.

Mundy, K. (2006). Education for All and the new development compact. International Review of Education, $52,5223-5248$.

OECD (1995). Governance in transition: Public management reforms in OECD countries. Paris: OECD.

OECD (2006). Demand-sensitive schooling? Evidence and issues. Paris: OECD.

OECD (2010). Investments in education: A troika of challenges. Paris: OECD.

OECD (2011). Private schools: Who benefits? Pisa in Focus, August, 1-4.

OECD (2012a). Better skills, better jobs, better lives: A strategic approach to skills policies. Paris: OECD.

OECD (2012b). How pronounced is income inequality around the world-And how can education help reduce it? Education indicators in focus, April. http://www.oecd.org/edu/50204168.pdf.

OECD (2013). Teachers for the 21st century: Using evaluation to improve teaching. Paris: OECD.

Sen, A. (1999). Development as freedom. Oxford: Oxford University Press.

Sosale, S. (2000). Trends in private sector development in World Bank education projects. Washington, DC: World Bank.

Tawil, S. (2013). Coming full circle? Reflections on the international education agenda for 2015 and beyond. NORRAG NEWSBite, March. http://norrag.wordpress.com/2013/03/20/coming-full-circlereflections-on-the-international-education-agenda-for-2015-and-beyond/.

Tawil, S. (forthcoming). Education post-2015: UNESCO and the international education agendas. ERF working paper no. 9. Paris: UNESCO Education Research and Foresight.

Tawil, S., Akkari, A., \& Macedo, B. (2012). Au-delà du labyrinthe conceptuel: La notion de qualité en éducation [Beyond the conceptual labyrinth: The notion of quality in education]. Paris: UNESCO Education Research and Foresight. http://unesdoc.unesco.org/images/0021/002175/217519f.pdf.

Tikly, L. (2011). Towards a framework for researching the quality of education in low-income countries. Comparative Education, 47(1), 1-23.

UNESCO (2000). Education for All: Status and trends 2000: Assessing learning achievement. Paris: International Consultative Forum on Education for All.

UNESCO (2004). EFA Global Monitoring Report 2005: The quality imperative. Paris: UNESCO.

UNESCO (2007). Literacy Initiative for Empowerment (LIFE) 2006-2015. Paris: UNESCO.

UNESCO (2008). EFA Global Monitoring Report 2009: Overcoming inequality: Why governance matters. Paris: UNESCO.

UNESCO (2009). Priority gender equality: Action plan 2008-2013. Paris: UNESCO.

UNESCO (2013). UNESCO principles for education and development beyond 2015. Paris: UNESCO Education Research and Foresight.

UNESCO IIEP [International Institute for Educational Planning] (2012). Les partenariats public-privé (PPP) dans l'enseignement de base [Public-private partnerships (PPPs) in basic education]. Paris: UNESCO IIEP.

UNESCO OREALC [The Regional Bureau of Education for Latin America and the Caribbean] (2008). Los aprendizajes de los estudiantes de América Latina y el Caribe [Student learning in Latin America and the Caribbean]. Santiago, Chile: UNESCO OREALC.

UNICEF (2006a). UNICEF education strategy 2006-2015. New York: UNICEF.

UNICEF (2006b). Manual: Child friendly schools. New York: UNICEF.

UNICEF (2007). Quality of education. New York: UNICEF.

UNICEF (2009). Child friendly schools. New York: UNICEF.

UNICEF (2010). Non-state education and public-private partnerships. New York: UNICEF.

UNICEF (2012). Education First: An initiative of the United Nations Secretary-General. New York: UNICEF.

UNICEF/UNESCO (2007). A human rights-based approach to Education for All: A framework for the realization of children's right to education and rights within education. New York/Paris: UNICEF/ UNESCO.

Vegas, E., \& Petrow, J. (2007). Raising student learning in Latin America. Washington, DC: World Bank.

Vinokur, A. (2003). De la scolarisation de masse à la formation tout au long de la vie: Essai sur les enjeux économiques des doctrines éducatives des organisations internationales [From mass schooling to lifelong learning: Essay on the economic implications of the education doctrines of international organisations]. Education et Société, 12, 91-104.

Wiseman, A. W. (2010). The uses of evidence for educational policymaking: Global contexts and international trends. Review of Research in Education, 34(1), 1-24.

World Bank (2005a). Education sector strategy update: Achieving Education for All, broadening our perspective, maximizing our effectiveness. Washington, DC: World Bank. 
World Bank (2005b). Expanding opportunities and building competencies for young people: A new agenda for secondary education. Washington, DC: World Bank.

World Bank (2006). From schooling access to learning outcomes: An unfinished agenda. An evaluation of World Bank support to primary education. Washington, DC: World Bank.

World Bank (2011). Learning for all: Investing in people's knowledge and skills to promote development. Washington, DC: World Bank.

World Bank/UNICEF (2009). Abolishing school fees in Africa: Lessons from Ethiopia, Ghana, Kenya, Malawi, and Mozambique. Washington, DC: World Bank.

Wright, C. (2009). Manual: Child-friendly schools. New York: UNICEF.

Zoundi, L. (2008). Les politiques de la Banque Mondiale relatives à l'éducation des filles dans les pays en voie de développement: Promesse d'équité ou renforcement des inégalités? [World Bank policies on the education of girls in developing countries: The promise of equity or the reinforcement of inequalities?]. Canadian Journal of Education, 31(1), 229-254.

Abdeljalil Akkari (Switzerland) is an associate professor at the Department of Education of the University of Geneva, and also a consultant for UNESCO and other international organisations. He was the dean for research at the Higher Pedagogical Institute HEP-BEJUNE in Bienne, Switzerland. His major publications include studies of educational planning, multicultural education, teacher training, and educational inequalities. Currently, his main research interests are international and comparative education.

Thibaut Lauwerier (France) is a research associate at the Faculty of Psychology and Education Sciences, University of Geneva. He is interested in the role of international cooperation in education policy development, education quality, literacy policies, non-formal education, and alternative forms of educational provision in the South. 